\title{
Pragmatic markedness of elocutive means of Russian advertising texts and the specifics of their translation into English
}

\author{
Liudmila Egorova ${ }^{1 *}$, and Marina Ryabova ${ }^{2}$ \\ ${ }^{1}$ Peoples' Friendship University of Russia (RUDN University), 6 Miklukho-Maklaya Street, Moscow, \\ 117198, Russian Federation \\ ${ }^{2}$ Russian New University, Institute of Humanitarian Technologies, 22 Radio St, Moscow, 105005, \\ Russian Federation
}

\begin{abstract}
The article discusses the problem of pragmatic conditionality of advertising texts in translation studies since the development of digital infrastructure, the transition to network principles of communication, global involvement of all countries in international market processes lead to the increasing importance of the quality of advertising texts translation into different target languages. As the communicative success of advertising texts is related to the elocutive component, the attention of researchers from Russia, Great Britain, the USA, Germany and other countries is focused on maximizing the retention of the pragmatic effect in the target language. The problem of conveying the elocutive structure of the advertising text when translating is relevant both for the Russian and the world context. The authors of the article adhere to the fundamental idea that the priority is the creation of a secondary text equivalent in terms of communicative aim. The research showed that the translated and source elocutively marked texts have their own distinctive pragmatic potential and the choice of translation technique depends on the task and function of the translated text. It is concluded that the development of digital technologies transformed the function of creolized components in the translation. The research results are of practical importance and can be used in the practice of teaching translation disciplines.
\end{abstract}

\section{Introduction}

The pragmatics of advertising texts is a priority object of modern research in the translation studies since the targeted orientation of advertising should ensure the implementation of its communicative task. With the development of digital infrastructure, the transition to network communication principles, the involvement of all countries in international market processes, the quality of advertising texts translation into different target languages is becoming increasingly important. Linguistic means should be selected very carefully, since any improper use of them may entail a discrepancy between the pragmatic component and the communicative intention, which causes an unplanned impact as well as a destructive

\footnotetext{
*Corresponding author: egorova-la@rudn.ru
} 
reputation. In this regard, the most urgent problem is the problem of recognizing the pragmatic content of advertising texts and its explicit expression in the translation text. Considering that the communicative success of advertising texts depends to a greater extent on the elocutive component, the attention of scientists is focused on the maximum preservation of the pragmatic effect in the target language. The problem of conveying the elocutive organization of the advertising text from the original language is relevant both for the Russian and for the world context.

\section{Subject and methods of research}

\subsection{Advertising text translation in modern linguistic research}

Linguistic research in the field of advertising text translation began relatively recently. The pragmatic potential of advertising is poorly investigated for many reasons. One of the most important factors is the fact that advertising in Russia started developing under new economic conditions only in the 90 s of the XX century.

Many researchers paid attention to conveying the specifics of advertising texts. For example, I.S. Alekseeva notes the need to include the advertising text in the "cultural environment of the target language" to "re-create it anew" [1, p. 132]. K. Reiss draws attention to different perception of advertising texts by different ethnic groups [2, p. 203] and develops, together with H. Vermeer, Skopos theory, which considers the advertising text in the context of cultural adaptation [3]. Subsequently, K. Nord develops Skopos theory, emphasizing the anthropological factor [4]. Thus, creating a text equivalent in the communicative aim is a fundamental idea in the advertising text translation. Consequently, the pragmatic component proves to be the criterion for the quality of the advertising text translation.

Any advertising text contains information affecting the emotions of the target audience to draw the recipient's perception to the advertised object. It is this feature of "the text to exert this or that influence that is called a pragmatic potential" [5, p. 31]. The pragmatic approach allows us to reveal the functional dualism of the advertising text: the pragmatic content, on the one hand, and the means of its explicit expression, on the other. The transformations in advertising crossing linguistic and cultural boundaries expand the concept of translation and generate new terms in translation studies (editing, adaptation, localization, etc.). The representation of advertising resources related to the pragmatic parameter is changing towards the elocutive possibilities in translation studies in a digital environment. The purpose of the study is to identify the means of elocution in Russian advertising texts and effective ways of conveying them in English.

\subsection{Advertising text elocutive means in contemporary information culture}

The contemporary information culture has changed significantly transforming linguistics into a new communicative paradigm, where correlations with the codes of various semiotic systems prevail. The higher pace of life contributes to the inclusion of advertising text in the digital space, where the translation process is currently taking place. Undoubtedly, the most difficult elements in the translation are precisely elocutive means possessing "subjectlogical (denotative) or connotative meaning" [6, p. 91], which must be arranged in the translated text to convey the necessary semantic relations. The translation of advertising text is a unique communicative activity. As a rule, it is rarely possible to accurately recreate the secondary text, which makes it difficult to establish clear boundaries between the source text and the translated text. Accordingly, elocutive means of advertising texts in Russian 
and English may represent completely different language means. Traditionally, elocution was based on figures of speech, emotionally decorating the text. I.R. Galperin is known to subdivide all expressive means into "phonetic, lexical and syntactic" [7, p. 103]. However, not all of them can be used to decorate the Russian advertising text and its translation into English, being replaced by the techniques that exert psychological pressure and manipulative actions. In other words, the figurative means is replaced by its performed function, making it possible to consider the advertising text as a fragment of influence on the target audience. This pushes translation from linguistics into interdisciplinary fields, thereby forming polycode semiotic systems within the framework of elocution.

I.V. Pekarskaya suggests a systematic understanding of the elocutives patterns, having developed the theory of elocution [8]. According to I.V. Pekarskaya, only elocutives are able to hold a person's attention [9, p. 72]. The mechanisms of unexpected techniques used in the advertising text translation are associated with a certain ideology of translation concerning its dominants. Adhering to the priority of the functional approach, one should pay attention to the rapidly growing gap between ideas about translation in the traditional sense and innovative views, when the translator creatively localizes the foreign language text into the context relevant for the recipient. In the case of advertising, such a creative adaptation seems to be more justified and legitimate. On the other hand, conveying the sense of the advertising text in a different cultural environment entails inevitable translation losses.

\subsection{Methods}

Analysis of translation solutions of over 100 advertising texts, which were classified by the type of the target audience, was used. The main types of advertising texts were selected (press release, newsletter, biography, by-liner article), where 768 examples of elocutive means in the original Russian-language text were identified. Then, the corresponding element in the translated text was analyzed and the translation solution was commented on.

The communicative approach defined the comparative-contrastive method as the main research method, which made it possible to compare elocutive means in Russianadvertising texts and their translations to determine the most effective translation techniques. Along with this, methods of continuous sampling and pragmatic interpretation of text components were used.

\section{Results}

Let us give an example of the elocutive means analysis in a translated biography advertising text type in English [10] and their implementation in a Russian-language text, and also characterize the main translation solutions. The text in question is posted on the website of Valentin Yudashkin and presented in two languages: Russian and English. 
Table 1. Comparative analysis of the translation solution when choosing elocution in the Biography text type in advertising

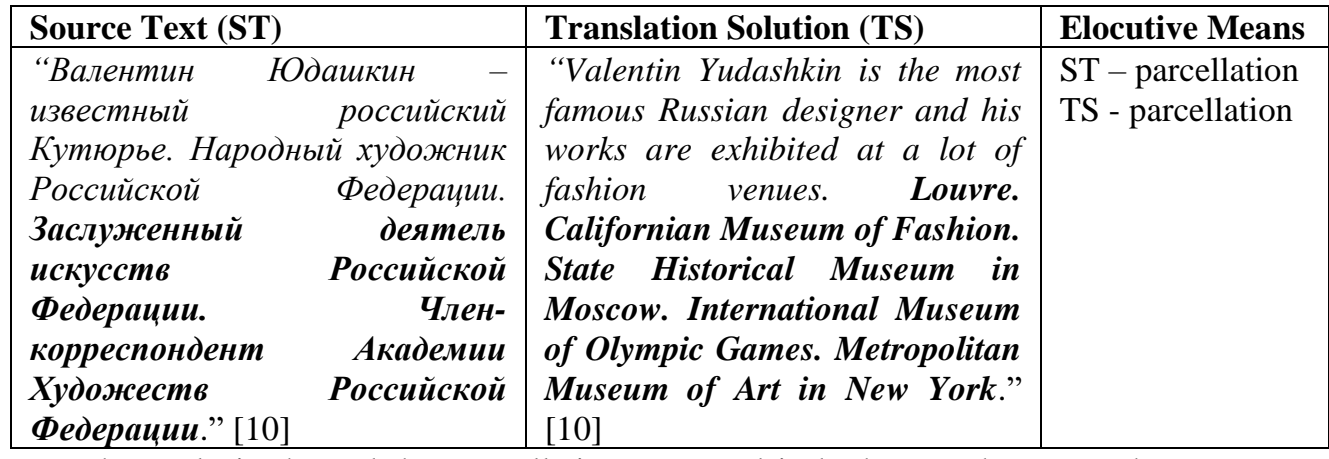

The analysis showed that parcellation was used in both texts, however, the sentences have a completely different semantic structure. The elocutive in the source text emphasizes the importance of V. Yudashkin's socio-cultural activities in Russia while in the translated text this idea is transformed into a story about the world's museums that keep his work. The translation solution assumed that the interests of the English-speaking audience are more related to the designer's achievements at the international level than to the fact of his reputation in Russia. Therefore, replacing one elocutive device with another can be considered quite reasonable and justified. The text in the English translation does not convey the cognitive information of the source text; it has changed significantly at the semantic level, however, it retained the source pragmatic potential. Consequently, such a translation can be considered functionally verified.

Next, we will comment on the meaning decoding in the "Press release" type of advertising text in the Russian-English language pair.

Table 2. Comparative analysis of the translation solution when choosing elocution in the "press release" type of the advertising text

\begin{tabular}{|c|c|c|c|}
\hline $\begin{array}{l}\text { Example } \\
\text { No. }\end{array}$ & Source Text (ST) & $\begin{array}{l}\text { Translation Solution } \\
\text { (TS) }\end{array}$ & Elocutive Means \\
\hline 1 & $\begin{array}{lr}\text { “Число } & \text { запросов } \\
\text { налоговых } & \text { органов } \\
\text { снизилось на } & \text { 33\%, и на } \\
\text { б0\% } & \text { уменьшилось } \\
\text { количество бумажных } \\
\text { документов } \text { бля } \text { ФНС } \\
\text { России. Компания сумела } \\
\text { сократить } & \text { сроки } \\
\text { подготовки } & \text { годовой } \\
\text { налоговой отчетности на } \\
\text { два месяца.”[11] }\end{array}$ & $\begin{array}{l}\text { "The number of } \\
\text { requests for relevant } \\
\text { documents decreased by } \\
33 \% \text { the number of } \\
\text { paper documents } \\
\text { intended for the Federal } \\
\text { Tax Service decreased } \\
\text { by } 60 \% \text { the allocated } \\
\text { preparation time for } \\
\text { annual tax reports } \\
\text { decreased by two } \\
\text { months."[11] }\end{array}$ & $\begin{array}{l}\text { ST - absent } \\
\text { TS - parallel } \\
\text { constructions, } \\
\text { lexical repetition of } \\
\text { the verb decrease }\end{array}$ \\
\hline 2 & $\begin{array}{l}\text { “Зарубежные визажсисты, } \\
\text { обладающие вселенской } \\
\text { популярностью, проведут } \\
\text { свои мастер-классыл.”[12] }\end{array}$ & $\begin{array}{l}\text { "The most talented } \\
\text { makeup artists of all } \\
\text { time will perform with } \\
\text { their masterclasses." }[12]\end{array}$ & $\begin{array}{l}\text { ST - hyperbole } \\
\text { TS - hyperbole }\end{array}$ \\
\hline
\end{tabular}


The communicative task of the Russian-language advertising text No. 1 was to implicitly influence potential customers to turn to the services of the international company Aeroflot, the prestige of which was confirmed by the HR-Brand 2018 award [11].

The press release contains elocutive means (parallel constructions, lexical repetition of the verb decrease), which differ from the source text ones. The stylistic devices selected by the translator subconsciously influence the choice of the recipient, modelling a positive image of the company. Parallel constructions and lexical repetition induce the conclusion of the target audience that the effectiveness of one stage of activity inevitably leads to improvements in another. As a result, the indirect impact of the advertising text develops trust and respect for the company.

In addition, the source text does not contain any elocutive means; the dominant feature is cognitive information, which is valuable for the Russian-speaking audience. The Englishspeaking recipient, on the other hand, is not focused on the laborious procedure of paperwork. At the same time, for the purpose of hidden advertising of the airline, the translator enhanced the press release with elocutive means, namely, adding parallel structures and lexical repetition.

Now let us analyze example No. 2, which is an English-language press release about an important master class at the international exhibition of cosmetics and perfumery "InterCHARM" [12]. The planned event should be hosted by renowned makeup artist Mimi Choi. To highlight the significance of the event, the translator uses hyperbole.

Hyperbole is also used in the Russian-language source. Both texts seem to contain the same elocutive means. However, the semantic structure is filled with a different lexical meaning and, accordingly, pragmatic potential. The elocution of the original text is aimed at attracting the consumers who value everything foreign as of particularly high quality. Moreover, the advertisement implicitly promotes the idea that the degree of popularity of foreign makeup artists makes the master class unique for the Russian-speaking target audience. This reliance on the mentality of the Russian-speaking linguistic personality ensures the correct perception of the advertising text.

Therefore, to convey the pragmatic component in the translation into English, it is necessary to address it to the English-speaking recipient, which makes the translator apply the substitution technique using the invariant of the elocutive means.

Let us consider the translation solutions in the "By-liner" type of advertising text.

Table 3. Comparative analysis of the translation solution when choosing elocution in the "By-liner" type of advertising text.

\begin{tabular}{|c|c|c|c|}
\hline $\begin{array}{l}\text { Example } \\
\text { No. }\end{array}$ & Source Text (ST) & $\begin{array}{l}\text { Translation Solution } \\
\text { (TS) }\end{array}$ & Elocutive Means \\
\hline 1 & $\begin{array}{l}\text { “В самом сердце } \\
\text { индустрии: отзыьвы } \\
\text { посетителей.”[13] }\end{array}$ & $\begin{array}{l}\text { "In the heart of the } \\
\text { industry: visitors' } \\
\text { feedback."[13]. }\end{array}$ & $\begin{array}{l}\text { ST - } \\
\text { personification } \\
\text { TS - } \\
\text { personification }\end{array}$ \\
\hline 2 & $\begin{array}{l}\text { “Как только выл } \\
\text { зарегистрируетесь, вы } \\
\text { получите доступ ко многим } \\
\text { полезным онлайн-сервисам и } \\
\text { обеспечит вам больмой } \\
\text { приток клиентов к } \\
\text { профилю вашей } \\
\text { компании.”[14] }\end{array}$ & $\begin{array}{l}\text { "Being registered, you } \\
\text { have an access to many } \\
\text { useful online services } \\
\text { and clients will flock to } \\
\text { see you profile."[14] }\end{array}$ & $\begin{array}{l}\text { ST - metaphor } \\
\text { TS - trite } \\
\text { metaphor }\end{array}$ \\
\hline
\end{tabular}

The research material was an advertising text (example No. 1), dedicated to the positive evaluation of the exhibition "Aquatherm" organizer [13]. The comparative analysis 
revealed functionally equivalent elocutive means (personification), but the influencing effect in the source text is enhanced by the presence of an intensifier. The Russian language is more emotional and even allows a combination of several intensifiers.

In the next paragraph (example No. 2) the elocutive means is a metaphor used to provide a motivational effect on the recipient [14]. However, though the same elocutive means were used in the translated and source texts, it is quite obvious that the translation was carried out using lexical and grammatical substitutions due to the translator's desire to convey the contained pragmatic potential as accurately as possible.

Let us move on to considering the implementation of elocutive means in the "Newsletter" type of advertising text and analyze the translation solutions applied.

Table 4. Comparative analysis of the translation solution when choosing elocution in the "Newsletter" type of advertising text.

\begin{tabular}{|c|c|c|c|}
\hline $\begin{array}{l}\text { Example } \\
\text { No. }\end{array}$ & Source Text (ST) & Translation Solution (TS) & Elocutive Means \\
\hline 1 & $\begin{array}{l}\text { “Положительное влияние } \\
\text { на развитие также } \\
\text { оказали рост добычи газа } \\
\text { в СНГ, рост добычи } \\
\text { нефти в России и рост } \\
\text { объемов продаж"[15]. }\end{array}$ & $\begin{array}{l}\text { "The positive influence on } \\
\text { the development was } \\
\text { supported by higher gas } \\
\text { production in the CIS, } \\
\text { higher oil production in } \\
\text { Russia and higher sales } \\
\text { volumes" [15]. }\end{array}$ & $\begin{array}{l}\text { ST - lexical } \\
\text { repetition; } \\
\mathrm{TS}-\text { lexical } \\
\text { repetition }\end{array}$ \\
\hline 2 & $\begin{array}{l}\text { "Наши сотрудники - наше } \\
\text { все!" [16] }\end{array}$ & $\begin{array}{l}\text { "Our employees are } \\
\text { young and talented and } \\
\text { they are the heart of our } \\
\text { company." [16] }\end{array}$ & $\begin{array}{l}\text { ST - hyperbole } \\
\text { TS - } \\
\text { personification }\end{array}$ \\
\hline 3 & $\begin{array}{l}\text { “Поверьте, нам не все } \\
\text { равно!” [16] }\end{array}$ & $\begin{array}{l}\text { "We do care about our } \\
\text { employees." [16] }\end{array}$ & $\begin{array}{l}\text { ST - imperative } \\
\text { verb; } \\
\text { TS - the auxiliary } \\
\text { emphatic do before } \\
\text { the main verb }\end{array}$ \\
\hline
\end{tabular}

The material under analysis is a news advertising text of the international company "Lukoil" [15]. The translated text (example No. 1) contains a lexical repetition of an adjective in a comparative degree as an elocutive means, helping to draw attention to the top results of the organization.

The source Russian-language text also has lexical repetition, but of a different part of speech: not an adjective, but a noun was used. The adjective "higher" chosen by the translator exactly conveys the pragmatic characteristics contained in the noun pocm /growth. Therefore, although the translation was made using the substitution technique at the part of speech level, the English language text can be considered equivalent in terms of elocutive means used.

Let us analyse one more example (example No. 2), which is also a newsletter, but from a different company, Reed Exhibitions [16]. Obviously, all employees are motivated by the words that they are appreciated. This attitude is expressed by the personification "the heart of our company", which generates a positive emotional response from the company staff.

Comparing the translation with the source text, we notice a stylistic discrepancy: in the original, the hyperbole was used: наши сотрудники - наше все/our employees are our everything. This stylistic device shows how much the company values its employees. The pragmatic content inherent in the Russian-language text was retained, however, with the substitution of one elocutive means for another, the hyperbole being replaced by personification. 
The auxiliary verb "do" emphatically used before the verb "care" (example No. 3) is quite expressive since it highlights the semantic content of the verb care underlying the company's concern for its employees. The source text has a functionally similar pragmatic nature, however, it is implemented using a different elocutive means (verb in the imperative form).

Undoubtedly, despite the use of different elocutive means in the source and translated texts, the pragmatic component is preserved and functionally identical.

The obtained results of a similar analysis of translation solutions in the study of over 100 advertising texts are summarized in generalizing Tables 5 and 6, which clearly demonstrate the frequency of elocutive means in Russian advertising texts and their translations into English.

Table 5. Statistics on the use of elocutive means in translations into English

\begin{tabular}{|l|l|l|l|l|l|l|}
\hline No & Elocutive Means & \multicolumn{3}{|l|}{ Types of Advertising Texts } & Total \\
\cline { 3 - 6 } & & Biography & $\begin{array}{l}\text { Press } \\
\text { Release }\end{array}$ & Newsletter & By-Liner & \\
& & & & & \\
\hline 1 & Personification & 2 & 35 & 78 & 114 & 229 \\
\hline 2 & Lexical Repetition & 76 & 22 & 14 & 18 & 130 \\
\hline 3 & Antithesis & 0 & 13 & 9 & 28 & 50 \\
\hline 4 & Metaphor & 17 & 25 & 34 & 47 & 123 \\
\hline 5 & Climax & 35 & 3 & 22 & 10 & 70 \\
\hline 6 & Allusion & 0 & 8 & 4 & 46 & 58 \\
\hline 7 & Epithet & 46 & 9 & 7 & 15 & 77 \\
\hline 8 & Idiom & 1 & 5 & 6 & 26 & 31 \\
\hline
\end{tabular}

Table 6. Statistics on the use of elocutive means in Russian source texts

\begin{tabular}{|l|l|l|l|l|l|l|}
\hline \multirow{2}{*}{ No } & Elocutive Means & \multicolumn{3}{l|}{ Types of Advertising Texts } & \multirow{2}{*}{ Total } \\
\cline { 3 - 6 } & & Biography & $\begin{array}{l}\text { Press } \\
\text { Release }\end{array}$ & Newsletter & By-Liner & \\
& & & & & & \\
\hline 1 & Personification & 2 & 34 & 74 & 110 & 220 \\
\hline 2 & Lexical Repetition & 77 & 22 & 19 & 21 & 139 \\
\hline 3 & Antithesis & 0 & 14 & 11 & 25 & 50 \\
\hline 4 & Metaphor & 17 & 25 & 31 & 50 & 123 \\
\hline 5 & Climax & 35 & 3 & 22 & 10 & 70 \\
\hline 6 & Allusion & 0 & 10 & 6 & 42 & 58 \\
\hline 7 & Epithet & 46 & 9 & 7 & 15 & 77 \\
\hline 8 & Idiom & 1 & 5 & 6 & 26 & 31 \\
\hline
\end{tabular}

Statistical analysis (see Tables 5 and 6) showed that the elocutive means of translated and source advertising texts practically coincide, with minor discrepancies. The most frequent are personification, lexical repetition, metaphor, epithet, and climax. However, it is worth noting that other figures of speech were also used as elocutive means: comparisons, paraphrases, phraseological units, rhetorical questions, etc. As for the translation solution when conveying them from Russian into English, the substitution technique prevails. 


\section{Conclusion}

The collected material allows us to make some observations that indicate a tendency to expand the range of problems in the translation of elocution in advertising texts. The sociocultural specificity of the material being translated is coming to the fore, the elocutive means of which have genre-forming properties. Examination of various types of advertising texts (press release, newsletter, biography, by-liner) revealed certain elocutive constants that are comparable in the source and translated texts. Elocutive means bring a sense only in the context of the communicative field, in combination with other elements of the text. Elocution in advertising discourse acquires importance as a special set of expressive means reflecting the system of values and traditions of the target audience. In the case of noncoincidence of elocutive means of the source and translated texts at the semantic level, the most frequent translation solution was substitution. However, despite the replacement of the lexical meaning of one elocutive means with another, the translation technique fully corresponds to the pragmatic content of the source text. We consider such a solution to be justified since this is caused by the difference in the English and Russian language systems.

Localization has become the dominant translation strategy. The adherence to an identical form and equivalent meaning in the source advertising text would make it difficult to understand and clutter up with unnecessary constructions. Conveying communicative tasks in advertising is carried out according to the host culture, taking into account the functional approach.

\section{Acknowledgments}

This paper was financially supported by the Russian Foundation for Basic Research, grant No. 20-012-22046.

\section{References}

1. I.S. Alekseeva, Text and translation: theoretical questions Moscow, (2008)

2. K. Reiss, Classification of texts and methods of translation, in Issues of the theory of translation in foreign linguistics (1978)

3. K. Reiss, H. Vermeer, Grundlegung einer allgemeinen Translationstheorie, Tübingen (1991)

4. C. Nord, Text analysis in translation: theory, methodology, and didactic application of a model for translation-oriented text analysis (Amsterdam; New York: Rodopi, 2005)

5. P.B. Hartley, Business Communication, Routledge (2013)

6. Yu.V. Zubkova, Organizational psycholinguistics. 4, 86 (2018)

7. I.R. Galperin, Essays on the style of the English language, Librokom (2012)

8. I.V. Pekarskaya, Bulletin of the Khakass State University. N.F. Katanova. 1 (31), 87 (2020)

9. I.V. Pekarskaya, Contamination in the context of the problem of the consistency of stylistic resources of the Russian language (Abakan, KSU, 2000)

10. About designer, in Fashion House "Valentin Yudashkin", March, 10, 2015 (2015). URL: http://yudashkin.com/en/dom-mody/o-dizajnere/ (Access: 05.08.2020)

11. Aeroflot takes HR-Brand Award 2018, in Company news. February, 22, 2018 (2019).URL: https://www.aeroflot.ru/ruen/news/61242?_preferredLocale=ru\&_preferredLanguageen (Access: 23.07.2020)

12. Mimi Choi's first appearance in Russia, in InterCHARM news, February, 4, 2019 (2019). URL: https://www.intercharm.ru/en/professional/news/mimichoi/ (Access: 15.07.2020) 
13. The first reviews, in Aquatherm news, February, 13, 2019 (2019). URL: https://www.aquatherm-moscow.ru/en/News/19-reviews-of-visitors/ 01.07.2020)

14. Online-services, in Visitors, January, 14, 2019 (2019). URL: https://www.wastetech.ru/en-gb/about/online-services.html (Access: 05.08.2020)

15. Lukoil announces ifrs financial results, in Press releases. November, 28, 2018 (2018). URL: $\quad$ http://www.lukoil.com/PressCenter/Pressreleases/Pressrelease?rid=308120 (Access: 29.07.2020)

16. Career, in Reed Exhibitions, November, 22, 2018 (2018). URL: https://www.reedexpo.ru/en/Main/Geography/ (Access: 01.08.2020) 